\title{
Morphofunctional condition of the pancreatic insular apparatus in old rats with alloxan- induced diabetes and its correction with lipoic acid
}

\author{
Yulia Klyueva ${ }^{1 *}$, Irina Danilova ${ }^{1,2}$, Viktor Emelianov ${ }^{1}$, Irina Gette ${ }^{1,2}$, and Ekaterina \\ Trofimova ${ }^{1}$ \\ ${ }^{1}$ Ural Federal University named after the first President of Russia B. N. Yeltsin, 620002, Mira st. 19, \\ Yekaterinburg, Russia \\ ${ }^{2}$ Institute of Immunology and Physiology of the Ural Branch of the Russian Academy of Sciences, \\ 620049, Pervomayskaya st., 106, Yekaterinburg, Russia
}

\begin{abstract}
The concentration of glucose and glycosylated hemoglobin in the blood of animals increases as a result of physiological aging. This is due to damage to the pancreatic insular apparatus and a decrease in the number and functioning of active $\beta$-cells. The development of alloxaninduced diabetes in old rats is characterized by a decrease in the number of islets of Langerhans, an enlargement of the preserved islets, and a sharp decrease in the number of active endocrine cells. The injection of lipoic acid partially corrected the morphofunctional condition of the islets of Langerhans and the biochemical values of the animals' peripheral blood.
\end{abstract}

\section{Introduction}

Diabetes attracts the attention of gerontologists as an age-dependent disease that shortens lifespan and modulates the basic aging mechanisms [1]. It is a well-known fact that the incidence of diabetes increases with age [2]. In addition, metabolic disorders expressed in diabetes (non-enzymatic glycation, oxidative stress) provoke aging without disturbances in carbohydrate metabolism [3]. Aging is characterized by the tension of the compensatory capabilities of the pancreatic insular apparatus as a reaction to peripheral insulin resistance [4]. Modulation of the morphofunctional state of insulin producing cells is a promising approach to the prevention and treatment of diabetes in old age [5, 6]. Lipoic acid (a natural antioxidant, anti-glycation agent, and geroprotector) is of special attention among the known methods for the pathogenetic correction of experimental diabetes in old animals $[3,7,8]$. Lipoic acid (LA) is able to stop the development of complications of experimental diabetes [9-11] and has proved to be an effective tool in diabetic polyneuropathy treatment $[8,12]$. However, age-related features of the lipoic acid have not yet been sufficiently studied. In this regard, it is of interest to study the state of pancreatic insular apparatus, the

\footnotetext{
* Corresponding author: klueva.iulia@urfu
} 
biochemical parameters of peripheral blood in the development of experimental diabetes in old animals and to evaluate the effectiveness of its correction using lipoic acid.

The aim of this study is to identify the features of compensatory reactions of pancreatic insular apparatus in old animals in alloxan-induced diabetes and its correction using lipoic acid.

\section{Materials and Methods}

The experiment covered 60 white male Wistar rats. The study was conducted in accordance with the ethical standards set forth in the "Ethical guidelines for the use of animals in research" and EU Directive 2010/63/EU "on the protection of animals used for scientific purposes". The study was approved by the ethics committee of the 2Federal State Institute of Immunology and Physiology, Ural Branch of the Russian Academy of Sciences (protocol No. 2 dated February 6, 2017).

The animals were divided into groups according to Table 1. The first group included young rats aged 6 months, the second group included rats aged 18 months (control), the third group included rats aged 18 months vaccinated with alloxan, the fourth group included rats aged 18 months vaccinated with alloxan plus lipoic acid. Animals were treated once in two days for 28 days one month after i.p. injections of the alloxan with an i.m. injection of $40 \mathrm{mg} / \mathrm{kg}$ b.w./day of lipoic acid («Oktolipen», Russia).

Modeling of diabetes was achieved by triple intraperitoneal injection of an alloxan into animals using a patented method [13]. The rats were injected with alloxan monohydrate in saline $(0.9 \% \mathrm{NaCl})$ at a dose of $170 \mathrm{mg} / \mathrm{kg}$ b.w. intraperitoneally to induce diabetes in $12 \mathrm{~h}$ fasted rats. Plasma glucose concentration was determined using enzymatic glucose oxidase method (Vector-Best, Russia), blood glycated hemoglobin (HbA1c) concentration was determined using the GLIKOGEMTEST kits, Russia. Plasma fructosamine concentration was determined using colorimetric L.N. Viktorova \& V.K. Gorodetsky method. Plasma malondialdehyde (MDA) concentration was determined spectrophotometrically by I.D. Stalnaya \& T.G. Garishvili method with thiobarbituric acid. The activity of peroxidase (EC 1.11.1.7) in the blood was determined by the rate of oxidation of indigo carmine with hydrogen peroxide using colorimetric T. Popov \& L. Neikovska method. The activity of catalase (EC 1.11.1.6) in the blood was determined using permanganometric A.N. Bach \& S.A. Zubkova method.

Pancreatic tissue samples were fixed in $10 \%$ buffered formaldehyde solution for 24 hours, then standard histological preparation of samples was performed using a Leica TP 1020 automatic processor (Leica Microsystems, Germany), followed by filling the material into paraffin in the Leica EG 1160 system (Leica Microsystems Germany). Sections 3-4 $\mu \mathrm{m}$ thick were made using Leica SM 2000R manual sled microtome (Leica Microsystems, Germany). During morphometry, the total number of pancreatic insulars was calculated. A study of pancreatic insulars included determining their diameter $(\mu \mathrm{m})$; total cell density, number of $\beta$-cells per $1 \mathrm{~mm} 2$ of endocrine tissue $(\mathrm{N} / \mathrm{mm} 2)$.

Antibodies to insulin and proinsulin (clone INS04 + INS05, Invitrogen, USA) were used to visualize insulin cells. Primary antibodies were used at a working dilution of 1: 200 and incubated at $4^{\circ} \mathrm{C}$ for 16 hours. Insulin was detected using the avidin-biotinperoxidase complex. In order to verify the protocol and exclude nonspecific staining, a negative and positive control feedback system was applied. For positive control of insulin staining, the so-called internal positive control was chosen, which is a priori known to have antigen in the sample. Islets of Langerhans of healthy animals are genuine positive control feedback. Negative controls were performed on similar sections of the pancreas according to the appropriate protocols, excluding primary antibodies. Positive insulin cells were 
counted using a Leica light microscope (Leica DM 2500, Germany), image analysis was performed in the VideoTest - Morphology 5.0 program (VIDEOTEST, Russia).

Results were processed using the Statistica 6.0 (DELL, USA), OriginPro 9.0 (Origin Lab, USA) and Microsoft Excel 2003 (Microsoft, USA) software. The homogeneity of two independent samples was tested using the nonparametric Mann-Whitney U and KruskalWallis tests were used. When testing statistical hypotheses, a significance level of 5\% was applied $(\mathrm{p}<0.05)$. Data are presented as mean \pm error $(\mathrm{M} \pm \mathrm{m})$.

\section{Results and Discussion}

\subsection{Bodyweight control in experimental animals}

According to Table 1, an increase in body weight of 3,25\% was observed in group 2 (age 18 months), bodyweight decreased in diabetic rats, which is a symptom of alloxan diabetes. With positive dynamics of biochemical blood parameters, a treatment of experimental animals with lipoic acid shows a decrease in body weight, which can be regarded as a beneficial effect of lipoic acid.

Table 1. Weight of rats at $30 \mathrm{~d}$ after alloxan-induced diabetes and after lipoic acid injections

\begin{tabular}{|l|c|c|c|c|}
\hline Value/group & $\begin{array}{c}\text { Young } \\
\text { group } \\
\mathrm{N}=10\end{array}$ & $\begin{array}{c}\text { Old group } \\
\text { (control) } \\
\mathrm{N}=10\end{array}$ & $\begin{array}{c}\text { Alloxan- } \\
\text { induced } \\
\text { diabetes } \\
\mathrm{N}=10\end{array}$ & $\begin{array}{c}\text { Alloxan-induced } \\
\text { diabetes } \\
\text { +lipoic acid } \\
\mathrm{N}=10\end{array}$ \\
\hline $\begin{array}{l}\text { Body weight } \\
\text { before the } \\
\text { experiment, g }\end{array}$ & $300 \pm 1,54$ & $554 \pm 0,17^{*}$ & $540 \pm 10,03^{*}$ & $528,4 \pm 18,76^{*, * *}$ \\
\hline $\begin{array}{l}\text { Body weight after } \\
\text { the experiment, g }\end{array}$ & $320 \pm 3,64$ & $572 \pm 0,78^{*}$ & $530 \pm 21,34^{*, * *}$ & $469,6 \pm 32,19^{* * * *}$ \\
\hline
\end{tabular}

Note: ${ }^{*} \mathrm{p}<0.05$ as compared to young group, ${ }^{* *} \mathrm{p}<0.05$ as compared to control group.

\subsection{Changes in blood biochemical values and pancreatic insular apparatus in rats during aging}

Data analysis shows that blood glucose level in 18-month-old animals increases by $63 \%$, compared with young animals. In group 2, the level of HbA1c does not change compared to group 1, while the blood fructosamine level in older animals increases by $22 \%$, reflecting the degree of glycemia in the short term. A state of oxidative stress developed in animals with age. The level of the secondary lipid peroxidation product, malondialdehyde, in group 2 increased by $33 \%$ compared to group 1 . It is interesting that compensatory reactions were observed with the enzyme link of the antioxidant defense with age: blood catalase activity was $64 \%$ higher than the values typical for young rats (table. 2 ).

Table 2. Biochemical blood parameters of rats at $30 \mathrm{~d}$ after alloxan-induced diabetes and after lipoic acid injections

\begin{tabular}{|c|c|c|c|c|}
\hline Parameter & $\begin{array}{c}\text { Young group } \\
\mathrm{N}=10\end{array}$ & $\begin{array}{c}\text { Old group (control) } \\
\mathrm{N}=10\end{array}$ & $\begin{array}{c}\text { Alloxan- } \\
\text { induced } \\
\text { diabetes } \\
\mathrm{N}=10\end{array}$ & $\begin{array}{c}\text { Alloxan-induced } \\
\text { diabetes } \\
+ \text { lipoic acid } \\
\mathrm{N}=10\end{array}$ \\
\hline Glucose, $\mathrm{mmol} / \mathrm{l}$ & $6,0 \pm 0,2$ & $9,8 \pm 0,04$ & $14,6 \pm 2,93^{*}$ & $10,06 \pm 0,06^{*}, \#$ \\
\hline
\end{tabular}




\begin{tabular}{|c|c|c|c|c|}
\hline $\begin{array}{c}\text { Glycated } \\
\text { hemoglobin } \\
\left(\mathrm{HbA}_{\mathrm{lc}}\right), \%\end{array}$ & $4,1 \pm 0,2$ & $5,075 \pm 0,3$ & $6,1 \pm 0,71$ & $5,7 \pm 0,37$ \\
\hline $\begin{array}{c}\text { Fructosamine, } \\
\mu \mathrm{mol} / \mathrm{g} \text { protein }\end{array}$ & $10,19 \pm 0,15$ & $12,41 \pm 0,79$ & $37,23 \pm 12,45^{*}$ & $25,4 \pm 1,7^{*}, \#$ \\
\hline $\begin{array}{c}\text { Catalase, } \\
\mu \mathrm{catal} / \mathrm{g} \mathrm{Hb}\end{array}$ & $0,61 \pm 0,045$ & $0,96 \pm 0,18$ & $1,65 \pm 0,15^{*}$ & $1,23 \pm 0,06^{*}, \#$ \\
\hline $\begin{array}{c}\text { Peroxidase, } \\
\mu \text { catal / g Hb }\end{array}$ & $12,05 \pm 3,01$ & $10,65 \pm 1,86$ & $5,65 \pm 2,31^{*}$ & $8,2 \pm 1,4^{*}, \#$ \\
\hline $\begin{array}{c}\text { Malonic dialdehyde, } \\
\text { nmol / g protein }\end{array}$ & $3,24 \pm 0,91$ & $4,31 \pm 0,77$ & $8,64 \pm 0,37^{*}$ & $6,32 \pm 0,1^{*}, \#$ \\
\hline
\end{tabular}

Note: ${ }^{*} \mathrm{p}<0.05$ as compared to control group, ${ }^{*} \mathrm{p}<0.05$ as compared to alloxan-induced diabetes.

Histological examination of the pancreatic tissue shows age-related changes in the structure of organs. Due to vascular congestion and interstitial edema, islets of Langerhans in animals aged 18 months were found near large vessels amid angiopathy development, vascular sclerosis, perivascular fibrosis, and parenchymatitis markers As compared to control group, the morphology of the islets is distinguished by an irregular structure and shape, the formation of processes, tails, and loose arrangement of cells (Fig.1)

A morphometric study of the pancreas revealed a decrease in the number of islets of Langerhans by 5.6 times. The surviving islets were large. Compared with a group of rats 6 months old, their average area almost doubled.

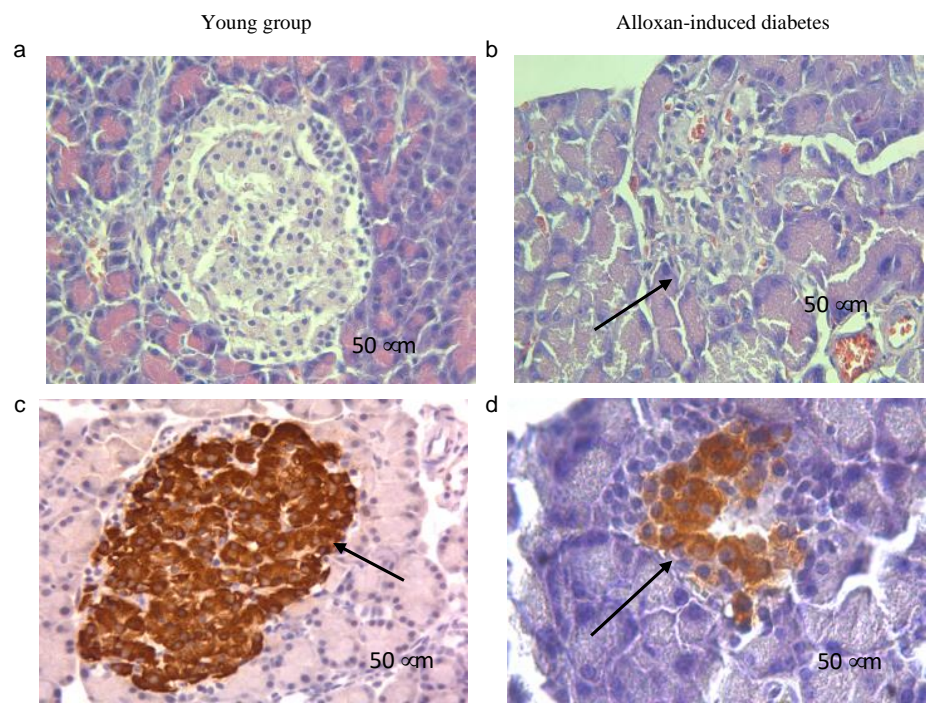



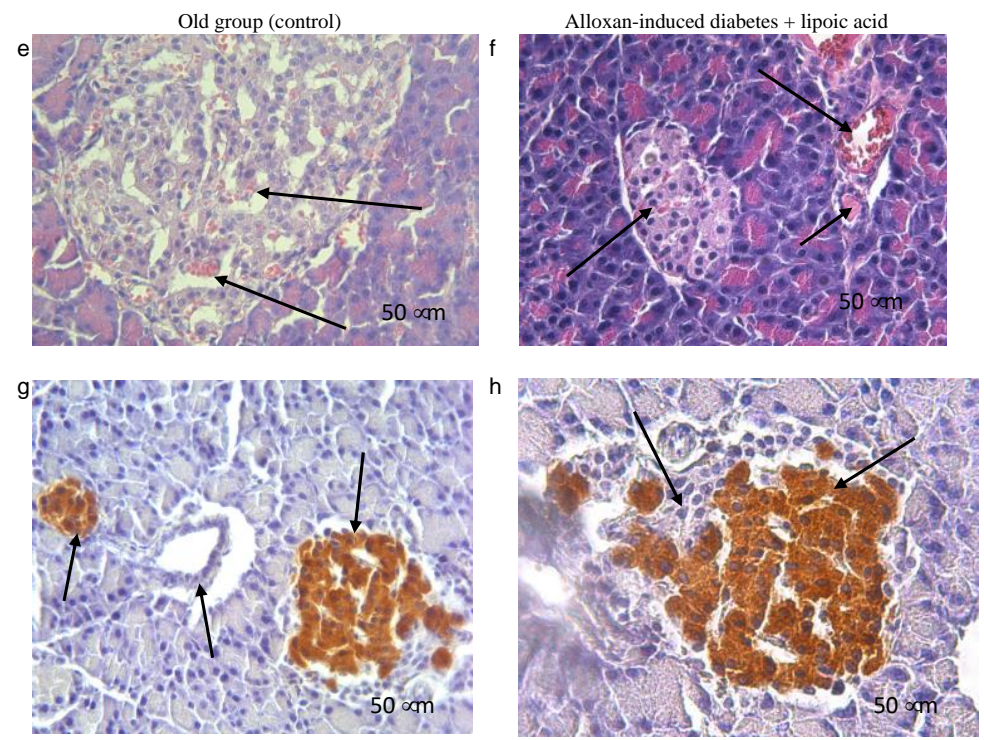

Fig. 1. Microphotographs of pancreas histology of different groups. H\&E staining 40x (a,b,e,f). Immunohistochemical staining for insulin $40 \mathrm{x}(\mathrm{c}, \mathrm{d}, \mathrm{g}, \mathrm{h})$, arrows indicate insulin positive cells. Young group $(\mathrm{a}, \mathrm{c})$, old group (control) $(\mathrm{e}, \mathrm{g})$, alloxan-induced diabetes $(\mathrm{b}, \mathrm{d})$, alloxan-induced diabetes + lipoic acid (f,h).

A decrease in the number of $\beta$-cells provoked a decrease in the cellularity of the islets by $25 \%$. Only $87 \pm 2,4 \%$ of the total number of surviving islets of Langerhans showed a positive reaction to insulin (Table 3 ).

Table 3. Morphometric analysis of the pancreatic islets of rats at $30 \mathrm{~d}$ after alloxan-induced diabetes and after lipoic acid injections

\begin{tabular}{|c|c|c|c|c|}
\hline Parameter & $\begin{array}{c}\text { Young group } \\
\mathrm{N}=10\end{array}$ & $\begin{array}{c}\text { Old group } \\
\text { (control) } \\
\mathrm{N}=10\end{array}$ & $\begin{array}{c}\text { Alloxan- } \\
\text { induced } \\
\text { diabetes } \\
\mathrm{N}=10\end{array}$ & $\begin{array}{c}\text { Alloxan-induced } \\
\text { diabetes } \\
\text { lipoic acid } \\
\text { N=10 }\end{array}$ \\
\hline $\begin{array}{c}\text { Number of pancreatic } \\
\text { islets, N/mm }{ }^{2}\end{array}$ & $1,8 \pm 0,2$ & $0,32 \pm 0,01$ & $0,24 \pm 0,17^{*}$ & $0,72 \pm 0,1^{*}, \#$ \\
\hline $\begin{array}{c}\text { Average area of the islets, } \\
\text { mcm }\end{array}$ & $13028 \pm 2089$ & $24001 \pm 1370$ & $18315 \pm 1200^{*}$ & $\begin{array}{c}17065,46 \pm \\
2309,18^{*}, \#\end{array}$ \\
\hline $\begin{array}{c}\text { Percent of pancreatic } \\
\text { islets with positive } \\
\text { insulin staining, \% }\end{array}$ & $100 \pm 0$ & $87 \pm 2,4$ & $49 \pm 1,07^{*}$ & $69 \pm 6,1^{*}, \#$ \\
\hline $\begin{array}{c}\text { Number of cells in the } \\
\text { pancreatic islets, N/mm }\end{array}$ & $8,67 \pm 0,24$ & $6,54 \pm 3,2$ & $2,31 \pm 2,8^{*}$ & $8,16 \pm 2,42^{*}, \#$ \\
\hline $\begin{array}{c}\text { Number of } \beta \text {-cells in the } \\
\text { pancreatic islets, N/mm }\end{array}$ & $7048 \pm 246$ & $5672 \pm 312$ & $23,02 \pm 4,1^{*}$ & $5934 \pm 512^{*}, \#$ \\
\hline $\begin{array}{c}\text { Percent of } \beta \text {-cells in the } \\
\text { pancreatic islets, \% }\end{array}$ & $81,3 \pm 1,7$ & $86,73 \pm 23,57$ & $0,99 \pm 0,001^{*}$ & $42,1 \pm 11,9^{*}, \#$ \\
\hline $\begin{array}{c}\text { Optical density of } \\
\text { cytoplasm in insulin+- } \\
\text { cells in the islets of } \\
\text { Langerhans }\end{array}$ & $0,56 \pm 0,01$ & $0,48 \pm 0,02$ & $0,35 \pm 0,01^{*}$ & $0,41 \pm 0,03 \#$ \\
\hline
\end{tabular}

Note: ${ }^{*} \mathrm{p}<0.05$ as compared to control group, ${ }^{*} \mathrm{p}<0.05$ as compared to alloxan-induced diabetes. 


\subsection{Changes in blood biochemical values and the condition of the pancreatic insular apparatus in old rats with alloxan-induced diabetes}

With the development of alloxan-induced diabetes, hyperglycemia of $14.6 \pm 2.93 \mathrm{mmol} / \mathrm{L}$, and an increase in the level of $\mathrm{HbA}_{1 \mathrm{c}}$ and fructosamine were recorded in the peripheral blood of control group No. 3 as compared to the same values in the group No. 2. The accumulation of protein glycation products was accompanied by a double decrease in enzyme activity peroxidase. The activity of catalase, an enzyme that catalyzes the decomposition of hydrogen peroxide, was increased by $80 \%$ as compared to intact animals of a similar age group. Also, plasma malondialdehyde level increased by 2 times (Table 2).

The pathological consequences of introducing alloxan to old animals have become the subject of histochemical and morphometric studies. Alloxan induced destructive changes (karyopicnosis, karyolysis, and cytoplasmic vacuolization) in the endocrine cells of the pancreatic islets. Cell membranes were fragmented or were absent, possibly due to circulatory disturbances in the microvasculature of the islets. The histological image of the pancreas demonstrates a high heterogeneity of the islets of Langerhans and the formation of endocrine structures of irregular shape. This is accompanied by edema in the interlobular connective tissue and the formation of lymphedema around the capillaries in the pancreas. Morphometric analysis revealed a decrease in the average area of pancreatic islets by $33 \%$ and a sharp decrease in cellularity by $65 \%$ compared to rats of a similar age. Immunohistochemical staining of pancreatic islets revealed a smaller number of insulin producing cells (Table 3 ). The number of preserved insulin-positive islets and $\beta$-cells in them, as well as the optical density of the cytoplasm, which identifies the functional activity of $\beta$-cells, decreased significantly.

\subsection{Changes in blood biochemical in old rats with alloxan-induced diabetes and lipoic acid injections}

Lipoic acid injected rats with alloxan-induced diabetes showed a decrease in blood glucose and fructosamine levels of $31 \%$ and $32 \%$, respectively. In addition, a decrease in the HbA1c level was reported. Lipoic acid injection reduced the level of MDA plasma and the activity of blood catalase by $27 \%$ and $25 \%$, respectively as compared to group No. 3 . Peroxidase activity in this group was $45 \%$ higher than in rats with alloxan-induced diabetes who were not lipoic acid injected (Table 2).

Immunohistochemical and morphometric analysis of the pancreatic tissue in lipoic acid injected rats with alloxan-induced diabetes revealed a positive trend. The number of damaged vessels, as well as foci of inflammation, decreased significantly compared to the group without correction. The shape of the islets of Langerhans normalized, and the number increased compared to the group not injected with lipoic acid. The number and cellularity of the islets, as well as the optical density of the cytoplasm in insulin-positive cells, indicating their functional activity, corresponded to those in intact animals (Table 3).

The results of the study correspond to data on unidirectional changes in metabolic processes in the body during aging and the development of diabetes [1]. An exacerbation of conditions characteristic to old animals was observed in the progression of diabetes, namely, hyperglycemia and the accumulation of glycated blood proteins. The state of oxidative stress, manifested in the accumulation of MDA not compensated by antioxidant enzymes, was especially pronounced under progression alloxan-induced diabetes in old rats.

It is widely known that non-enzymatic glycation and oxidative stress in hyperglycemia are connected. It is believed that hyperglycemia induces the production of reactive oxygen 
species due to the disruption in the normal functioning of the respiratory chain of mitochondria and the overproduction of superoxide and hypochlorite by phagocytic leukocytes. In addition, glycation reduces the activity of antioxidant defense enzymes and NO synthase, depletes the reduced glutathione pool, and stimulates aldose reductase, which promotes the accumulation of sorbitol [3]. As a result of the non-enzymatic process, the accumulation of end glycation products occurs, irreversibly damaging the structural proteins and the intercellular matrix. This leads to the development of diabetic angiopathies and neuropathies [3, 9-12].

Due to the fact that GLUT-2 proteins transfer alloxan into the cell, reactive oxygen species (ROS) are generated, resulting in the selective destruction of $\beta$-cells [14]. In alloxan-induced diabetes, oxidative stress exacerbates the generation of ROS inside the islets of Langerhans caused by the prooxidant alloxan, which damages $\beta$-cells, and, as a result, provokes insulin deficiency.

A complex of morphological methods confirmed damage to $\beta$-cells during the study. A decrease in the number and cellularity of the islets of Langerhans, a decrease in the optical density of the cytoplasm in insulin-positive cells indicated functional deficit of the insulinsynthesizing system in rats during aging, which was exacerbated by alloxan-induced diabetes. Thus, the morphological and functional characteristics of the islets of Langerhans in old animals and the revealed biochemical disturbances are connected.

Their successful joint correction with lipoic acid confirms this connection. Endogenous antioxidant and vitamin a-like factor proved its high potential in the treatment of pathologies associated with oxidative stress and hypoxia [7,8]. The anti-glycation effect of lipoic acid is beneficial in the treatment of diabetes. The intracellular effects of lipoic acid are due to its endogenous metabolite - dihydrolipoic acid, which has antioxidant and antiglycating activity due to thiol groups $[8,12]$. It is important that the age-related features of acid application in the clinic and in the framework of the experiment are not yet investigated. Our results indicate successful joint correction of hyperglycemia, the accumulation of glycated blood proteins and the product of malondialdehyde lipid peroxidation under the influence of lipoic acid. Lipoic acid injections not only improved the morphological image of the pancreas in alloxan-induced diabetes but also brought a number of indicators to the level of animals of the younger age group (cellularity of the islets, optical density of the cytoplasm in insulin-positive cells). In view of the above, the antidiabetic and geroprophylactic effect of lipoic acid in old rats with alloxan-induced diabetes can be stated.

\section{Conclusions}

1. The formation of hyperglycemia, the accumulation of glycated blood proteins, and oxidative stress are typical for rats aged 18 months.

2. The development of alloxan-induced diabetes in old rats exacerbates age-related biochemical disorders, which leads to damage to the morphological structure of the pancreatic insular apparatus and a decreased functional activity of insulin-positive cells.

3. Lipoic acid injection of old rats with alloxan-induced diabetes reduces the severity of structural disorders of the pancreatic insular apparatus, improves the functional activity of insulin-positive cells, which leads to a decrease in hyperglycemia, the accumulation of glycated blood proteins and oxidative stress.

\section{Acknowledgements}

The work was supported by RSF grant № 16-15-00039P 


\section{References}

1. V.V. Emelianov, V.N. Meshchaninov, P.A. Sarapultsev, Gospitalniy, 2, 20 (2007)

2. IDF Diabetes Atlas, $9^{\text {th }}$ ed. (IDF, 2019)

3. V.V. Emel'yanov, Adv. Geront., 7, 1 (2017)

4. Z. Gu, Y. Du, Y. Liu, L. Ma, L. Li, Y. Gong, H. Tian, C. Li, AGE, 34, 1393 (2012)

5. S. Yagihashi, W. Inaba, H. Mizukami, J. Diabetes Investig., 7, 155 (2016)

6. B.B. Boland, C.J. Rhodes, J.S. Grimsby, Mol. Metab., 6, 958 (2017)

7. D. Tibullo, G. Li Volti, C. Giallongo, S. Grasso, D. Tomassoni, C.D. Anfuso, G. Lupo, F. Amenta, R. Avola, V. Bramanti, Inflamm. Res., 66, 947 (2017)

8. V.A. Tutelyan, A.A. Makhova, A.V. Pogozheva, E.V. Shikh, E.V. Elizarova, S.A. Khotimchenko, Vopr. Pitan., 88, 6 (2019)

9. K. Winiarska, D. Malinska, K. Szymanski, M. Dudziak, J. Bryla Biochimie., 90, 450 (2008)

10. M.A. Kandeil, K.A. Amin, K.A. Hassanin, K.M. Ali, E.T. Mohammed, J. Diab. Compl., 25, 31 (2011)

11. V.V. Emelianov, D.V. Leontev, A.V. Ishchenko, T.S. Bulavintseva, E.A. Savateeva, I.G. Danilova, Biophysics, 61, 906 (2016)

12. S. Tesfaye, A.J.M. Boulton, A.H. Dickenson, Diabetes Care, 36, 2456 (2013)

13. I.G. Danilova, T.S. Bulavintceva, I.F. Gette, S.Y. Medvedeva, V.V. Emelyanov, M.T. Abidov, Biomed. Pharmacother., 95, 103 (2017)

14. M. Radenković, M. Stojanović, M. Prostran, J. Pharmacol. Toxicol. Methods, 78, 13 (2016) 